\title{
Bureaucratic Communication in Provincial Government of Special Capital Region of Jakarta
}

\author{
Muh. Kadarisman \\ \{kadarisman.bkn@gmail.com\} \\ Universitas Muhammadiyah Jakarta, Indonesia
}

\begin{abstract}
In the Provincial Government of Special Capital Region of Jakarta, there is currently an inability to deliver information, and a lack of equality between the people of Jakarta and bureaucracy in communication. This is one of the problems, so that in the long run it impacts on the inability of the Jakarta to realize good governance. The research aims to analyze bureaucratic communication in the Jakarta. The research uses descriptive methods, and qualitative approaches. The results of the research: formal and informal bureaucratic communication in the Jakarta in general has given the best results, being able to achieve the desired targets even though this achievement is not optimal. Civil Servants have tried to understand and carry out every stage of communication and good communication techniques, so as to eliminate or minimize any obstacles that occur. The bureaucratic communication emphasizes the interdependence of relations between people, bureaucracies, and with the community.
\end{abstract}

Keywords: Communication, Bureaucracy, Civil Servants.

\section{Introduction}

The performance of Provincial Government of Special Capital Region of Jakarta is influenced by, among others, the quality of communication that is developed inside the daily activities of this public institution, because Provincial Government of Special Capital Region of Jakarta consists of a number of bureaucratic personnel (Civil Servant). To operate such a public organization (bureaucracy), public communication must be developed. This communication is an accountability system for a government institution that would be sufficient to fulfill important requirements for the quality improvements of public service. The government must be able to broaden alternative public service providing systems, as well as support information or set standards that can ensure accountability in public service well [1].

To execute current governmental tasks and future demands, which are becoming more and more abundant and complex, the development of public manpower is a must [2]. It must be emphasized that the bureaucracy in Provincial Government of Special Capital Region of Jakarta is an instrument for ensuring the successful operation of an administrative system. Bureaucracy functions based on division of labor, hierarchy of authority, impersonality of relationships, regulation of actions, and technical ability to carry out tasks and functions as the provider of governmental administration. As such, public service that is carried out by Provincial Government of Special Capital Region of Jakarta is one of activities that are prioritized and closely scrutinized by the public. However, there appears to be an anecdotal 
indication that bureaucratic services in Indonesia suffers from low quality throughout governmental institutions, as frequently reported by various mass media [3].

In the matter of internal and external communications among Civil Servants of Provincial Government of Special Capital Region of Jakarta, there are several issues that can hinder or challenge the communication process, which in turn affect the performance. In addition to problems that have been previously discussed, such as distortion, there are issues that are related to information overload, emotion, unsuitable or improper or unethical language, anxiety during communication, selective filtering or perception, etc. As such, bureaucratic communication to be discussed here refers to the process in conveying information and ideas of Civil Servants inside the government organization to reach the goals that have been set. This communication by public organizations consists essentially of internal and external activities inside Provincial Government of Special Capital Region of Jakarta that refers to the actions of one or more individuals involving sending and receiving messages, which in the process can be distorted by disturbances, occurring in certain contexts, have certain effects, and have the opportunity for feedbacks.

In addition, the initial field observations in Provincial Government of Special Capital Region of Jakarta showed that there was unintelligibility in dissemination of information, as well as imbalances in communication between Jakarta general public and bureaucracy. These are some of the causes that in the long term may result in the inability of Provincial Government of Special Capital Region of Jakarta to provide good governance. Inside the Provincial Government of Special Capital Region of Jakarta bureaucracy, there are interdependencies, and these require coordinating actions, whether internally (intra-institution) as well as externally (inter-institution). In carrying out their tasks and functions, Civil Servants in Provincial Government of Special Capital Region of Jakarta are inevitably dependent of the communication activities among themselves and across institution as well as with the general public, whether formally or informally. This governmental communication is an essential part of conveying and receiving professional and public information [4].

However, recently there has been a significant increase in the complexity of the tasks as well as demand for transparency in public service, which is also very dynamic, in Provincial Government of Special Capital Region of Jakarta. As such, the reality of bureaucratic communication in Provincial Government of Special Capital Region of Jakarta is faced with profound challenges from many aspects, such as performance, budgeting, and various policies that must be formulated, implemented, and evaluated. And how Civil Servants in Provincial Government of Special Capital Region of Jakarta communicate? The preliminary field observations show that essentially Civil Servants rely on verbal and written communications. Whereas communication issues in Jakarta public are related to verbal content $(15 \%)$, vocal interest or intonation (35\%), and body language (50\%). The main method to convey messages among Civil Servants of Provincial Government of Special Capital Region of Jakarta is spoken communication, such as daily conversation, explanations in the forms of presentations, speeches at certain events, discussions of certain topics, gossips, etc [5].

The positives of verbal communications among the Civil Servants of Provincial Government of Special Capital Region of Jakarta are the speed of information dissemination and instant feedbacks among personnel forming dialoges, as well as instant responses to these verbal messages. Public service managements Provincial Government of Special Capital Region of Jakarta must also build public trust in accordance to public demands and aspirations for improved quality of public service [6]. The biggest deficiency in verbal communication that frequently appears in this public organization is when the message goes through several 
Civil Servants in Provincial Government of Special Capital Region of Jakarta, cascading through more and more personnel, the chance of message distortion increases.

One of communication principles is every behavior has the communication potential. Communication behavior is an action or conduct of a communicator during information exchanges, whether verbal or non-verbal, present among Civil Servants of Provincial Government of Special Capital Region of Jakarta. A good example related to this subject is the communication behavioral problems of Basuki Cahaya Purnama, popularly called Ahok, during his role as the Jakarta governor that were frequently highlighted by the mass and social media [7]. There were different assessments of Ahok's style among communication experts. However, in short, he had a tendency to ignore the intonation of his speech during public speaking. He tended to speak in a combative tone, which was often irrelevant to the context of the message. Based on public observations, Ahok's public communication was often classified to violate communication ethics for public figures [8].

Presumably, Ahok's public communication received less public sympathy, although he was considered successful in solving crucial problems in Provincial Government of Special Capital Region of Jakarta. Furthermore, his verbal communication during his speech in Kepulauan Seribu, Provincial Government of Special Capital Region of Jakarta, brought him into legal troubles because it was considered religious defamation towards Islam. That issue showed a failure in communication that had implications in starting the conflicts between Ahok and several Islamic organizations. The phenomenon of Ahok's communication behavior implicitly showed how a leader's public communication could affect public perceptions. This means that the success of a regional leader can be determined by how communication behavior is conducted in the leadership [8]. In the governmental communication field, the factors that influence communication behavior of a leader in a bureaucracy can be determined by vertical and horizontal communication types in formal and informal situations, in addition to governmental communication facing hierarchical organization structures [7].

The implementations of those two communication patterns can create an organizational environment that is very conducive to success. In governmental communication, the role of communication of the regional leader determines the performance of Civil Servants. Moreover, the degree of success or performance of a leader can be well received by the public if it is communicated properly [9]. The results of the initial field observations clearly showed that the distortions of communication among Civil Servants of Provincial Government of Special Capital Region of Jakarta were in the forms of inaccuracies or different interpretations of the message and the recipients. This takes place because recipients interpret those messages according to their own thought patterns and experiences. Additionally, there is also an evasion of communication among Civil Servants, that is the phenomenon in which message is discredited by recipients because they are not in favor of the communicator as well as the content of the message. This phenomenon contributes to the slow progress of bureaucratic reformation and communication patterns of governmental institutions [10]. This account shows the importance of the study titled "Bureaucratic Communication in Provincial Government of Special Capital Region of Jakarta".

\section{Theoretical Framework}

The etymology of communication is that the word is derived from the Latin word communis, which means creating or developing togetherness between two or more people. 
Communication is also derived from the Latin word communico, meaning to share [11]. According to Vardiansyah [12], communication study is the effort to convey messages among humans, and because of it, this field is further defined as the study of how humans convey messages to each other. When a person is involved in a communication situation, the person has interests in or similarities to others; interests in the physical features or the manners of communication of others; similarities to languages or meanings of symbols used in communication [12].

Communication is a way to interact to each other and conducted by individuals, groups, organizations, and public to convey messages to other individuals (second party) with certain intentions that can influence the behavior of the recipients. Based on this definition, communication can be considered a process that involves several components. Majid [11] stated that based on the understanding of communication above, communications among people clearly can only occur when there is a communicator conveying a message to a recipient with certain intentions. This means that communications take place only when they are supported by sources, messages, media, recipients, and effects. These ingredients can be called communication components or elements [13].

Starting from this understanding of communication, we can emphasize that governmental organization communication (bureaucracy) is the process of sending and receiving various organizational messages in formal or informal groups from governmental organization policies (bureaucracy) that are interconnected and influence each other in order to achieve the goals of the organization. Therefore, indicators or aspects of bureaucratic communications are sending and receiving various governmental organization messages (bureaucracy); those messages are intended for formal or informal groups from a governmental organization; Civil Servants who are interconnected and influence each other; also achieving the goals of governmental organization [14]. Inside the policies for bureaucratic communication, there is an approach used to analyze policy implementations as proposed by Edwards III [15]. There are four variables in public policies in relation to communications, which are communications, resources, dispositions or attitudes, and bureucratic structure (Figure 1).

Implementations will occur effectively if the parameters and objectives of the policies are understood by the individuals responsible for achieving the goals of the policies. The clarity of the policy parameters and objectives therefore must be communicated accurately to the task implementers. Consistency or uniformity from the basic parameters and objectives must be conveyed so that the implementers understand those parameters and objectives accurately. Communication in an organization is a complex and complicated process. A party may hold on to or spread it for a certain personal interest. In addition, different sources of information will result in different interpretation. To achieve effective implementations, whoever is responsible to carry out a duty must understand whether they are capable of doing it.

This is different from a social organization where people socialize among each other. In the case of bureaucratic communication, there is a formal or informal communication. Formal communication is a communication that has been agreed upon by the organization and oriented to serve itself in the forms of procedural protocols inside the organization, productivity, and various duties that must be performed inside the organization, for examples: memoranda, office notes, press releases, formal documents, etc. Whereas informal communication is a communication that has been agreed upon socially, and not oriented towards the organization but more for its members as individuals. It is emphasized that bureaucracy works based on jurisdictional hierarchy dependent on leadership that allows for effective control and positive performance [16]. Especially if authority of the top leader (the strategic-apex) is decentralized to implement leaders (the middle-line). 
Is decentralized structure allowing for the formation of a professional bureaucracy that results in increased organizational performances and bureaucracy can be accountable for these delegated authorities. The presence of order in the procedures associated with rules and regulations according to Kadarisman [17] aims to guarantee sustainability of governmental duties and roles. If these rules are rigidly implemented, it will produce an unprofessional bureaucracy that is reflected on the implementation of duties and functions related to the current rules (rule-driven professionalism) and makes irresponsive and uninnovative bureaucracy.

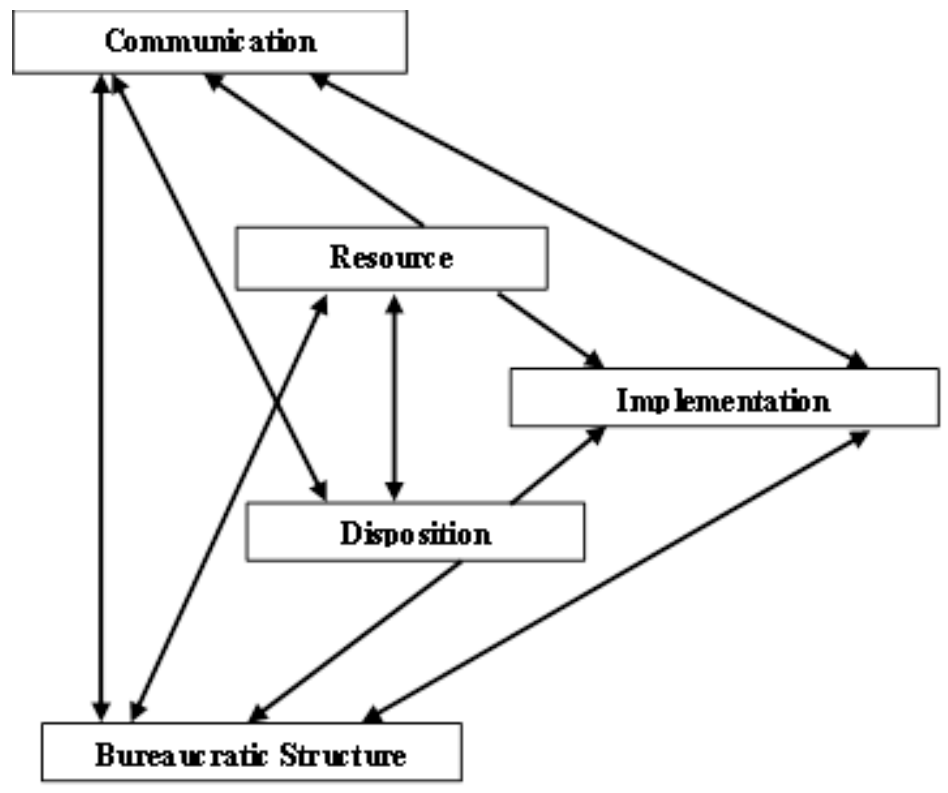

Fig. 1. A Diagram of Direct and Indirect Effects in Bureaucratic Communication [15].

Those formal and informal communications works as a synergy, as described by Effendy [18], in which formal communications usually follow a chain of command as defined in the organization structure (organigram). Whereas in the informal system, there is a presence of social relationships that allow an authoritative clout, which has been transmitted in the formal system, to be accepted. Therefore, the position of authority is very important in the formal and informal systems. First is the formal communication. Formal communication, according to Mulyana [19], is a communication in line with the organizational structure, such as that up, down, or horizontal. Furthermore, Blake dan Haroldsen [20] state that there are many similar characters in organization and formal channel communications. Those characters of formal channel communication, according to Shibutani in Blake dan Haroldsen [20], are (1) the communication channel functions as the standard for every report coming from various sources, so that they can be verified; and (2) the source of message is recognized and thus trusted.

The formal channel communication can be defined as having stable rules, well defined procedures, rules, and sanctions, and being able to be followed by different people. Participants can be recognized and trusted, and is responsible. Also, there is an accurate route of communication. Second is the informal communication. Organizational communication, 
according Wiryanto in Romli [21], the transmission and reception of various organizational messages in formal or informal groups of an organization. Formal communication is the communication that has been agreed upon by the organization and oriented towards its interests. The contents consist of procedures inside the organization, productivity, and various tasks that must be performed in the organization. Whereas informal communication is the communication that is accepted socially. Organizational communication can also defined as the process to create and exchange messages in a network of relationships that are interdependent to anticipate uncertain or changing environments.

Informal communication is the communication that is accepted socially and oriented not towards the organization but more towards the individual members [22]. When bureaucracy is not tightly connected to procedural protocol and basic rules, but instead is moved by the mission achieved by the organization (mission-driven professionalism), it will therefore create professional bureaucracy that carries out its duties and functions effectively and innovatively, and possesses high work ethos [17]. In the perspective of Indonesia public administration, there are several pathologies that generate unprofessional bureaucrats or personnel in performing their duties and functions, which in turn produce low motivation to change and innovate.

These pathologies are results of overall behavior and managerial styles that are often employed by the top management (the strategic-apex) in a public organization hierarchy. Managerial and leadership styles that are feudalistic and paternalistic are heavily influential on the organizational performance, such that the bureaucrat at the medium and low levels are reluctant to perform and take new steps in an effort to improve public services [23]. The low interest in making changes and innovations in this case is also caused by managerial styles that are not conducive to creating a bureaucracy that is responsive and innovative. It is no surprise that ability of the organization and its personnel is very low. In a pro status-quo view of the top management, all developments in science and computer and information technologies are considered threats to leader's carrier and position. The quality of public service provided by a bureaucracy is closely linked to the ability and quality of the said bureaucracy.

The ability of government bureaucrats, in addition to the development and increase of knowledge and expertise of the individuals, is also affected by the organizational systems, such as work orientation, organizational structure, leadership model, and renumaration that is accepted by personnel. Other factors that become the main causes that influence bureaucratic competency are the new employee recruitment processes, which often ignore meritocratic aspects and the needs of the organization. It also is no surprise that in practice, Indonesian bureaucracy often gets overwhelmed in anticipating every new changes and aspirations. The effect from this phenomenon is a decrease in the qualities of organizational performance and public service [10]. Messages in the communication processes in government institutions are the items that given by the communicators to the recipients. These messages can be transmitted through face-to-face interactions or other communication media, such as telephones, letters, telegram, and internet media (emails and social media). The contents can be scientific knowledge, entertainment, information, advice, or propaganda. In English, messages can be also called contents or information.

Message recipients, or receivers, are formal or informal parties that become the targets of the message sent by the source, or the second person in this communication process. The receivers can consist of one or more individuals, or groups, or party, or even the government itself. Recipients can be addressed with various names such as the public, target, communicator, or audience. In a communication process, it is understood that the existence of an audience is caused by the presence of a source. There will not be an audience, if there is no 
source. Recipients are an important element in the communication process because they are the communication target. If a message is not received by the recipients, or they do not understand the message wholly or partly, there will be problems that will demand changes, whether at the source, message, or channel.

Because of that, understanding our audience is a basic principle in communication. By understanding the characters of the audience, the chance to succeed in the communication process opens up. In addition, media or channels are needed in the governmental bureaucratic communication. Media, in this case, are the tool to send messages and sources to the recipients. There are several views on channels or media. There is a view that media can be in many forms, such as interpersonal communication senses, which can be considered a communication medium. In conjunction with written communication among Civil Servants in Provincial Government of Special Capital Region of Jakarta, this method includes memoranda (memo), reports, facsimile, announcement, suggestion forms, electronic mails, SMS, news bulletin, etc (Public Relations of The Provincial Government of Special Capital Region of Jakarta, 2018). The advantage of written communication among Civil Servants in Provincial Government of Special Capital Region of Jakarta is the presence of hardcopies that can be used as authentic and formal proofs.

Moreover, written communication provides a means of more structured and well-thought out ideas than spoken interactions among Civil Servants. The disadvantage for such a method is that written communication requires more time to complete, which may make the bureaucracy more complicated and longer. For example, a report that is composed in hours or days or even months may be presented orally in a short time. The feedback does not happen instantly either, or sometimes a written communication does not invite a feedback, such when receiving a memorandum, each Civil Servants has different interpretation. Finally, another non-verbal communication method in the bureaucracy of Provincial Government of Special Capital Region of Jakarta is gesture or body language, especially that unaccompanied by spoken words [24] can be used to emphasize feelings among Civil Servants or with superiors during the communication process. For example, an idea expressed by Civil Servants can change meaning whether the individual smiles or frowns.

When Civil Servants records a report in a meeting without the presence of the reporting employee, it would hard to find the emphases of the report because of the lack of stressed words as well as gestures that reflect the feelings of the personnel. Misunderstanding of messages also occurs among Civil Servants in Provincial Government of Special Capital Region of Jakarta, between superiors and inferiors, as well as between personnel at the same hierarchical level.

\section{Research Methods}

This study employs descriptive methods to obtain empirical data on the bureaucratic communication in Provincial Government of Special Capital Region of Jakarta. The data are analyzed to produce proper interpretations, and describe accurately the behavior and action of group and individual phenomena at the empirical level. Data are collected from January to June 2018 (six months). Qualitative approach is further used to observe and capture the reality, and examine individual and group behaviors, as well as the experience of the informants. According to Moleong [25], qualitative approach in a research is defined as a procedure that produces descriptive data in the forms of written or spoken words from 
respondents and of their behavior being observed. A qualitative study is intended to form a guidance for substantive theory development based on data. Qualitative method is used to produce inferrences from the collected data [26].

As such, qualitative approach in this study is an investigative process to understand social or human issues, based on the creation of holistic Figurean formed with words, and reports of informants' views in details. Using triangulation technique [27], researches crosscheck the data obtained from the informants, and compare the results of interviews with observations of bureaucratic communication of Civil Servants in Provincial Government of Special Capital Region of Jakarta. The overall data consist of primary and secondary data. The main data source of this study with the qualitative approach is words and actions and the rests are addition, documents, etc. This study is conducted on informants consisting of Civil Servants in Provincial Government of Special Capital Region of Jakarta from the following agencies: Governor Chief of Staff office, Public Relation and Protocol Bureau, Regional Human Resources, and Public Empowerment Agency.

Purposive method is used to choose informants using certain criteria based on basic capacity of competence [28]. In a qualitative study, a researcher is also a research instrument as an interviewer employing a technique called participant observation, complete with indepth interviews with key persons and detailed daily records of events taking place in the field. The key informants in this study are the leadears (agency chiefs) in Provincial Government of Special Capital Region of Jakarta, who also important sources of important primary data. For supporting informants, that is administrative positions, are a group of positions consisting of functions and duties related to public service and governmental and developmental administrations.

The data collection method consists of: 1) Interviews; information is collected by direct face to face interactions between researcher and informants as repondents. In depth interview is performed with Key and Supporting Informants using an interview guide to collect data and uncover information from the Informants. 2) Observations; information is gathered by observing directly the bureaucratic communication of Civil Servants in Provincial Government of Special Capital Region of Jakarta. 3) Focus Group Discussion (FGD); discussions are carried out with the authoritative agents to examine the issues in bureaucratic communication of Provincial Government of Special Capital Region of Jakarta. 4) Documentation; reports, journal articles, books, and other literature resources related to the study.

As supporting instruments, researches utilize voice recorder, maps, camera, notes, and other stationery to assist in data collection. Data are analyzed using emic and etic viewpoints to produce deep Figurean (think description) and find verstehen. To establish the trustworthiness of the data, we triangulate the data by crosschecking the trustworthiness degree of the gathered information. We compare our interview results from the key informants, supporting informants, and general public who are directly involved in the field [29].

Data analyses in this study are based on Kadarisman's [27] method, in which they involve systematic collection and construction processes of data gathered from interviews, field notes, and documentations. This information is organized into categories, assigned units, synthesized, constructed into patterns, sorted based on importance, and summarized to become more understandable for self as well as others [30]. Therefore, data analyses are focused on the processes on the field and data collection. 


\section{Results and Discussion}

\subsection{Sending and Receiving Organizational Messages in Provincial Government of Special Capital Region of Jakarta}

In this discussion, we first present one of the results from the Focus Group Discussion (FGD) that since this is about a governmental organization, in this case the bureaucracy of Provincial Government of Special Capital Region of Jakarta, consisting of Civil Servants, the bureaucratic dynamics are marked by interactions among Civil Servants in this institution. Those interactions and communications continuously flow to and from several directions. It should be emphasized that, based on the hierarchy, the communications inside the bureaucracy of Provincial Government of Special Capital Region of Jakarta go in two directions, vertical and horizontal.

Furthermore, communication that flows from one level to the one below it makes up the downward vertical communication, that between superiors and subordinates [21]. This downward communication functions as job instructions, covering the the reasons of the task (job rationale) [31]. Moreover, the communications also include current procedures and practices, as well as motivations for the lower ranked Civil Servants to improve performance and increase morale. These communications are not always conveyed verbally, but often in the forms of letters, memos, reports, depositions, emails, SMS, etc.

The results of in-depth interviews with key and supporting informants show that communication among Civil Servants in Provincial Government of Special Capital Region of Jakarta also occurs from subordinates to superiors, which is called upward communication. The functions of this upward communication are to provide information on tasks that have been given, whether they have been accomplished properly or not. Furthermore, subordinates may also report to their superiors on the problems that arise during task implementation, recommendations on how to achieve task completion, getting more references for superiors to make decisions, subordinates' understanding of tasks, and evaluations to self and tasks. The upward communication can also increase loyalty and appreciation of lower level Civil Servants to the institutions. Upward communications are needed not only to report successes of any degree, but also to find out challenges and failures so that superiors/managers understand the states of the organizations and Civil Servants under their leaderships, so that improvements can take place. Meanwhile, results from triangulation processes as well as observations show that upward communications does not only consist of verbal communications, such those conveyed in meetings and discussions in which subordinate Civil Servants are involved to provide information on the condition of field implementation, but also comprise of written reports, surveys on personnel attitudes, questionnaires for Civil Servants members, etc. Which can be used to determine future policies.

Horizontal communication is defined as information exchanges between Civil Servants members from the same level of bureaucratic hierarchy. The functions of this type of communications include improving task coordination as well as problem solving; sharing information; resolving conflicts; and developing professional relationships. Formal horizontal communications among Civil Servants of Provincial Government of Special Capital Region of Jakarta are needed to provide shortcuts for the long-winded hierarchical channels. However, from managerial aspects, these communications do not always end up well. Communications will end well when Civil Servants have the proper interpretation and motivation of the available information, and when the opposite happens, improper communication may have negative effects on the leaderships. 


\subsection{Formal and Formal Messages for Groups in Provincial Government of Special Capital Region of Jakarta}

Results of in-depth interviews with key informants show that principally effective communications in a bureaucracy must create the same understanding in the senders and recipients whether they are intended to formal or informal groups inside government institutions. Because there is an agreement and same understanding between the serving and served parties, therefore the general public can expect better services from the government. The leaderships in Provincial Government of Special Capital Region of Jakarta in this democratic atmosphere are required to have the ability to communicate, persuade, persevere in getting messages across, tolerate differences, and listen to criticisms. They must also be willing and able to reach understanding and consensus.

In-depth interviews with supporting informants produce results that describe the bureaucratic communications in Provincial Government of Special Capital Region of Jakarta as dynamic, symbolic, systematic, contextual, and consequential in relation to Civil Servants interactions. Communication processes are also related to the thought patterns and characters of the parties involved, as well as the types of messages and media used, therefore, it is very challenging to produce effective communication in the bureaucracy of Provincial Government of Special Capital Region of Jakarta. Furthermore, among Provincial Government of Special Capital Region of Jakarta residents, bureaucratic communications always show the higher proportion of government authority than the rights of the public to speak and communicate their opinions. As such, the rhetoric's of authority frequently dominate all the decisions used in the regional developments.

During FGDs, participants express the needs for Provincial Government of Special Capital Region of Jakarta to be more democratic in their communication by allowing more inputs from the general public, so that cohesive relationships develop between Civil Servants in Provincial Government of Special Capital Region of Jakarta with the public, as a part of civil political reformations. Henceforth, bureaucratic reformation in Provincial Government of Special Capital Region of Jakarta to improve the bureaucratic processes can take place accordingly and result in significant improvements in public service. Communications are an important element in the existence of Provincial Government of Special Capital Region of Jakarta organization, because they are utilized to carry out various managerial functions, from planning, organizing, governing, to monitoring. Communication facilitates the members of an organization to achieve goals of individuals and institution, respond to and implement changes experienced by the organization, coordinate activities, and perform all relevant organizational activities.

In an effort to achieve the goals of Provincial Government of Special Capital Region of Jakarta, it is important to develop and maintain harmonious communication among Civil Servants and agencies. The roles of the Public Relation unit of Provincial Government of Special Capital Region of Jakarta can include creating congenial relationships among Civil Servants, providing information to the internal public, and providing recommendations on the work of the subordinates and the successes of coordinating the agencies. The organization of Provincial Government of Special Capital Region of Jakarta may lose much of the potential of their manpower if they do not prioritize the two-way communication among the agencies effectively. It is, thus, necessary for Provincial Government of Special Capital Region of Jakarta to pay close attention to their organizational communication hardware's in the workplace. 
There are sometimes misunderstandings between superiors and subordinates or among Civil Servants on the messages or information in the bureaucracy of Provincial Government of Special Capital Region of Jakarta. Although they often do not reflect the true value of universal democracy, which emphasizes the freedom of association, expression, and pursuit of suitable livelihood, and other virtues that do not respect freedom as well as differences. Basically, the elites of a bureaucratic structure must be able to create effective communications, without coercion, and honor civility in communication democracy. Communication is considered effective when the signal conveyed and intended by the sender or message source is in accordance with that received and understood by the recipient.

Additionally, there are five factors that can be used to measure whether the communication in Provincial Government of Special Capital Region of Jakarta takes place effectively. Those are: 1) There is an understanding of the message by the recipient; 2) It provides comfort to the parties involved, resembling that in a maintained relationship; 3) It can influence the behavior of others; 4) It can improve relationship; and 5) It produces the intended results in the form of correct actions by recipients. Even though these effective communications can be supported by similar characteristics of the parties involved, there are issues that have the potential to be obstacles, in this case, matters that are related to the information flow inside the public organization of Provincial Government of Special Capital Region of Jakarta.

Robbins [32] describes the factors that have the potential to obstruct the goals of effective communication; those are 1) filtration or manipulation of information aimed at generating gains or losses for the recipients; 2) selective perceptions, in which individuals see or listen only to what they need. This action tends to ignore the broad substance of the message, and only underline the needed information.; 3) emotion or feeling of the recipients at the arrival of the message. If the recipient is currently upset, the message sender will find difficulties in getting the right response. Likewise, if the sender is in anger, the recipient will give different response to the intended message.

The problems according to the stakeholders are the lack of communications that are fast, clear, and transparent, and minimal overall coordination's between Provincial Government of Special Capital Region of Jakarta and external stakeholders (National Government, Ministry of Interior, and other related agencies) as the critical and fundamental part. These external stakeholders consider the performance of Provincial Government of Special Capital Region of Jakarta is not optimal and has not met expectation. Provincial Government of Special Capital Region of Jakarta thus can still improve their performance to meet the expectation of general public. A public organization does not work in vacuum nor in a perfect world. Therefore, in its efforts to carry out its functions, this organization will not only work on one certain issue, but on various public services and other duties.

Public services and other tasks outside the duties and functions force a public organization to be always dynamic in its effort to change, whether gradual or radical, so that it can always be useful and provide values to the general public. In this effort to change, a bureaucratic leadership ability is needed to ensure and invite all stakeholders to fully support the policies and actions in their own capacities.

\subsection{Relationship Among Civil Servants Members in Provincial Government of Special Capital Region of Jakarta}

FGD results on this indicator show that communication in Provincial Government of Special Capital Region of Jakarta generally is described as actions or activities to convey ideas 
or information from one Civil Servants to others. As such, the main concern in this case is idea management and openness, or the choice to be close or inaccessible. However, it should be noted that the choice to be open or close is not an individual's decision but an agreement by the parties that influence each other. Individuals who are involved in relationships with others will continuously maintain a boundary inside them whether to be open or close.

In the more special teamwork context in Provincial Government of Special Capital Region of Jakarta, communication is a process in exchanging information, trust, and emotion among members to develop understanding and trust in creating good relationships. Toha [33] identifies communication from corporate and marketing communication perspectives as "selling ideas" and obtaining agreement to and support for the ideas, which in the end what the message sender basically want is behavioral changes from the recipients in their willingness to accept/agree to the ideas.

The directions of communications generally consist of three directions, those are vertical, horizontal, and diagonal. The vertical communication is the flow of communication that follows hierarchical relationships (superiors to subordinates, and vice versa). The horizontal communication flows among colleagues of the same bureaucratic levels. Whereas the diagonal communication flows from superiors to subordinates, or vice versa, however, they are not from the same units. Inside the daily life of a traditional organization, the largest part of communication tends to flow downward, which is manifested in the forms of instructions, directives, explanations, etc. Along with the dynamics of maturation development of the organization, communication becomes more open to those three directions, because task completions require involvements from more than one unit.

Communication accessibility is the availability of opportunity to communicate. Generally, the degree of communication capacity among stakeholder depends on the opportunity to communicate among themselves. The most effective method is informal direct conversations [34], therefore in the past, the physical distance and available space determined the availability of communication opportunities. However, in the era of advanced information technology, physical distance does not impede communication accessibility as more and more communication media become more available. The cutting-edge communication equipment provides stakeholders an accessibility that is more open and not limited by distance and available space. Because of this, the availability of communication media that are proportional among the stakeholders determines the communication effectiveness among them.

The quick communication strategy described by Ilyas [34] categorizes communication patterns into four spectrum; those are aggressive, assertive, responsive, and non-assertive. Ilyas further elaborates that when assertive and responsive communications are combined, they can be used as an instrument of negotiation, problem solving, or conflict resolution, and become the most optimal method of communication. This type of communication is considered to best facilitate the rights and feelings of every stakeholder involved in a program, and provide a room for dialogue, in which every stakeholder is guaranteed openly to express their feelings on the program that is or will be carried out. Moreover, in such an environment, the needs, aspirations and competency of every stakeholder will become the focus [35].

Strategy and efforts of a public organization to influence stakeholders involved are essential to the success of the planning and execution of its programs. In the context of building effective teams, the effort to influence stakeholders must begin with grouping the stakeholders based on their influences and businesses. To achieve the correct grouping, mapping of stakeholders can be performed using net-map before the beginning of programs. 


\subsection{The Communication in Achieving the Organizational Goals of Provincial Government of Special Capital Region of Jakarta}

The communication indicator in "Achieving the Organizational Goals of Provincial Government of Special Capital Region of Jakarta" is obtained from FGD results. The roles of languages as an instrument in bureaucratic communication to the general public cannot be overstated. The multi-ethnic nature of Jakarta population poses potential problems that can hinder development processes. As such, this phenomenon must be faced and anticipated by Provincial Government of Special Capital Region of Jakarta well, with the view that when this diversity is united, it can become a great strength for Provincial Government of Special Capital Region of Jakarta to become an advanced and prosperous region, parallel to other world metropolitans.

Among the instruments to unite the region, Provincial Government of Special Capital Region of Jakarta must be able to use the correct bureaucratic communication to their public. Language in bureaucracy has important roles in communicating its tasks and functions in managing the government mechanism effectively and efficiently. This description is supported by the results from in-depth interviews of all informants, both key and supporting, who describe the unfavorable situations when the bureaucrats do not have the ability to use the language correctly with their subordinates as well as the general public. According to Cassirer [36], the uniqueness of humans is not on their ability to think but on that to form languages. This means that the ability of a bureaucrat is determined by his correct and respectful way to communicate with the general public.

The triangulation process results show that bureaucracy is expected to have significant roles in all planning processes of Provincial Government of Special Capital Region of Jakarta, which has been adjudicated in their public policy. However, in practice, the roles of bureaucracy in regional governments are often doubted to be able to enliven and add dynamics in democratic processes in this diversed population, because bureaucracy generally is time consuming and inflexible.

Observation results affirms that to achieve their goals, Provincial Government of Special Capital Region of Jakarta require their regional mechanisms called government and governance. In this case, Provincial Government of Special Capital Region of Jakarta are essentially services to the public. Provincial Government of Special Capital Region of Jakarta are created not serve themselves but provide services to the general public as well as create conditions that every member of the society develop their ability and creativity through interactive communication optimally [37]. This condition has been practiced by bureaucrats in Provincial Government of Special Capital Region of Jakarta.

As such, Provincial Government of Special Capital Region of Jakarta are expected to be the leader in public service implementation. The spirit of regional autonomy is essentially the effort to make Provincial Government of Special Capital Region of Jakarta to be independent in carrying out governmental duties, development, and public empowerment in Jakarta. Because of that, Provincial Government of Special Capital Region of Jakarta Jakarta must always be cognizant in responding the needs and aspirations of the public. With the implantation of regional autonomy, public services are hoped to be fast, accurate, and affordable, so that this public service organization becomes robust [38]. The dynamic development of Jakarta society, along with the improvement of quality of life, has increased the awareness of Jakarta inhabitants of their rights and obligations as citizens.

Jakarta residents have become more critical and bolder to express their demands and aspirations, and monitor the performance of their regional government. The public has become 
more resolute in demanding their bureaucrats in Provincial Government of Special Capital Region of Jakarta to realign their positions and revitalize their roles to provide public services. The habit of giving out orders should be changed to serving, and of authoritative to helpful. The changes should point to the directions of flexibility, collaborative, and communicative, in addition to eliminating approaches full of slogans and replacing them with realistic and pragmatic practices.

\section{Conclusion}

Bureaucratic communication in Provincial Government of Special Capital Region of Jakarta generally has the effects that produce useful results, which means that the results are correct and able to reach the intended target, even though these outcomes are not optimal. To achieve effective communication, the bureaucracy in Provincial Government of Special Capital Region of Jakarta has endeavored to understand and perform every step of communication and its techniques used by Civil Servants to eliminate or reduce obstacles that may be present.The communication techniques include, among others, the use of languages that are easily understood, intonations that are correct and relevant to the expression, correct gesture or body language, eye contact, and interlocutors who actively listen to the communication. This condition has been displayed by the communicators (Civil Servants members) and recipients, who have the same understanding of the message, which creates comfort, influences attitude, increases favorable social relationships, and in the end results in positive and conducive actions.

Effective communication in the bureaucracy of Provincial Government of Special Capital Region of Jakarta asserts the interference that explains relationships among people (Civil Servants and public), inter and within bureaucracy (Civil Servants members), and inter-public, whether formal or informal. Informal communication is needed to support the success of formal communication in Provincial Government of Special Capital Region of Jakarta, and this condition has been continuously maintained to sustain good relationships among members of the organization and the general public. Bureaucracy in Provincial Government of Special Capital Region of Jakarta generally has understood that the most important element in communication is not only on what is written or spoken but what reflects robust characters, which are built on the foundation of strong integrity of the bureaucrats (Civil Servants). This is reflected by the facts that, in Provincial Government of Special Capital Region of Jakarta, corruption indictments are rare and professional ability of Civil Servants keeps improving, because they are supported by good integrity, ability, knowledge, skill, and attitude.

\subsection{Recommendation}

a) Communication inside the bureaucracy of Provincial Government of Special Capital Region of Jakarta is aimed at coordinating, synchronizing, and harmonizing parts of or whole duties and functions of the organization. As such, it is recommended that this is maintained or even improved according to the dynamics of the organization and the era of public information transparency, because without improved communication, this public organization will only display individual aspects of Civil Servants members and not present the exceptional collaborative aspects. It is also 
important to strengthen the actualization of public involvement in bureaucratic communication in di Provincial Government of Special Capital Region of Jakarta.

b) The biggest issues in the formal communication channel in Provincial Government of Special Capital Region of Jakarta are the possibility of distortion or problems in conveying the information to the higher level, because every connection in the communication flow has the potential of creating misunderstanding. To overcome this problem, one of the recommendations is to reduce the levels in the organization structures. The fewer the number of connections, the smaller the chance of misunderstanding. Organizational structure that is more horizontal with fewer levels but with more control will help reduce the distortions.

c) With the presence of effective communication in the bureaucracy of Provincial Government of Special Capital Region of Jakarta, it is recommended to maintain this condition well, because it has been shown that it has united Civil Servants to reach organizational goals optimally. Communication successes in bureaucracy have important roles to maintain the integrity of the bureaucracy, because fluid and constructive communication can create openness among Civil Servants members and stimulate collaborative problem solving. On the other hand, dreadful communication can cause new problems in the bureaucracy and even damage the organization of Provincial Government of Special Capital Region of Jakarta, because messages are not perfectly conveyed from the sender to the receiver. For that, other methods are needed to communicate according to the available conditions. Those specific communication methods are intended to overcome the differences in communication with people of different attitudes and emotions in the bureaucracy, because not everyone understands the intentions of messages in the same manner.

\section{References}

[1] B. Baharuddin, "Akuntabilitas Pelayanan Publik: Studi Kasus Pelayanan Perizinan Mendirikan Bangunan di Kota Makassar,” Mimb. J. Sos. dan Pembang., vol. 31, no. 2, pp. 263-270, 2015.

[2] M. Kadarisman, Manajemen Pengembangan Sumber Daya Manusia. Jakarta: RajaGrafindo Persada, 2017.

[3] R. A. Fitriawan, D. K. S. Putra, and C. Nugroho, "Analisis Komunikasi Birokrasi Atas Kualitas Layanan Publik di Wilayah Administrasi Kabupaten Bandung,” J. Channel, vol. 5, no. 1, pp. 59-82, 2017.

[4] U. Silalahi, "Komunikasi Pemerintahan: Mengirim dan Menerima Informasi Tugas dan Informasi Publik," J. Adm. Publik, vol. 3, no. 1, 2004.

[5] Humas, Hubungan Masyarakat Pemerintah Provinsi DKI Jakarta. 2018.

[6] Lembaga Survei Indonesia (LSI), Undang-Undang No. 25 Tahun 2009 tentang Pelayanan Publik. 2015.

[7] Y. M. O. Buluamang, "The Relationship Between Communication Behaviors Of District Head With Public Images And Public Expectation,” J. Stud. Komun. dan Media, vol. 22, no. 1, pp. 75-87, 2018.

[8] E. Hasan, "Komunikasi pemerintahan cetakan kedua," Bandung: Refika Aditama, 2010.

[9] J. A. Mau, "Peran Komunikasi Pemerintahan terhadap Peningkatan Partisipasi Masyarakat dalam Pembangunan Bersumber Anggaran Pembiayaan Negara," JISIP J. Ilmu Sos. dan Ilmu Polit., vol. 4, no. 2, 2015.

[10] E. H. Susanto, "Kelambanan Reformasi Birokrasi dan Pola Komunikasi Lembaga Pemerintah," J. Aspikom, vol. 1, no. 1, pp. 109-123, 2017.

[11] A. Majid, "Perencanaan Pembelajaran Mengembangkan Kompetensi Guru," PT Remaja Rosdakarya. Bandung, 2011. 
[12] D. Vardiansyah, "Pengantar ilmu komunikasi," Bogor Ghalia Indones., 2004.

[13] D. Pace, R. Wayne; Faules, Komunikasi Organisasi. Bandung: Remaja Rosdakarya, 2010.

[14] Wiryanto, Pengantar Ilmu Komunikasi. Jakarta: Grasindo, 2005.

[15] G. C. Edward III, Implementing Public Policy. Washington: Congressional Quarterly Press, 1980.

[16] R. AWZA and Z. Sonessa, "Citra Kepemimpinan Bupati Kuansing di Kecamatan Inuman." Riau University.

[17] M. Kadarisman, Sistem Manajemen Pelayanan Publik. Jakarta: UMJ Press, 2013.

[18] O. U. Effendy, Humas Membangun Citra Dengan Komunikasi. Bandung: Remaja Rosdakarya, 2005.

[19] M. Dedy, "MA, Ilmu Komunikasi Suatu Pengantar.” PT. Remaja rosdakarya, Bandung, 2010.

[20] R. H. Blake and E. O. Haroldsen, "Taksonomi Konsep Komunikasi, alihbahasa Hasan Bahanan," Surabaya: Penerbit Papyrus Surabaya, 2005.

[21] R. Khomsahrial, "Komunikasi Organisasi Lengkap,” Jakarta PT Grasindo, 2011.

[22] J. DeVito, Komunikasi Antarmanusia (penerjemah. Wahyu YI. Prihantini Y). Tangerang: Karisma Publishing Group, 2011.

[23] M. Kadarisman, Metode Kepemimpinan. Jakarta: UMJ Press, 2011.

[24] E. A. Griffin, A first look at communication theory. McGraw-Hill, 2003.

[25] L. Moleong, Metodologi Penelitian Kualitatif. Bandung: PT. Remaja Rosdakarya, 2010.

[26] Sugiyono, Metode Penelitian Kuantitatif, Kualitatif dan $R \& D$. Bandung: Anggota Ikatan Penerbit Indonesia (AIPI), 2013.

[27] M. Kadarisman, Metodologi Penelitian. Jakarta: UMJ Press, 2010.

[28] E. Ardianto, Metodologi Penelitian untuk Public Relations. Bandung: Remaja Rosdakarya, 2010.

[29] J. W. Creswell, Research Design Pendekatan Kualitatif, Kuantitatif, dan Mixed. Yogyakarta: Pustaka Pelajar, 2014.

[30] N. K. Denzin, "The elephant in the living room: Or extending the conversation about the politics of evidence," Qual. Res., vol. 9, no. 2, pp. 139-160, 2009.

[31] H. Widhiastuti, "The Effectiveness of Communications in Hierarchical Organizational Structure," Int. J. Soc. Sci. Humanit., vol. 2, no. 3, pp. 185-190, 2012.

[32] S. P. Robbins and T. A. Judge, "Perilaku Organisasi Buku 1," Jakarta: Salemba Empat, 2008.

[33] Y. Panji, "Komunikasi dan Konstruksi masyarakat Konsumen (Suatu perspektif Cultural Studies)," Iij, Farid Hamid hery Budianto, Ilmu Komun. Sekarang dan tangtangan Masa Depan,(Jakarta Kencana), ed, vol. 1, 2011.

[34] Y. Ilyas, Kiat sukses manajemen tim kerja. Gramedia Pustaka Utama, 2003.

[35] Z. Dai and H. Li, "On Verbal Competence," J. Arts Humanit., vol. 3, no. 3, pp. 17-22, 2014.

[36] E. Cassirer and A. A. Nugroho, Manusia dan Kebudayaan: Sebuah esai tentang manusia. Gramedia, 1990

[37] A. Suryono, "Budaya Birokrasi Pelayanan Publik," J. Ilm. Adm. Negara, vol. 1, no. 2, pp. 49$58,2001$.

[38] A. F. Wijaya, "Akuntabilitas Aparatur Pemda dalam Era Good Governance dan Otonomi Daerah," J. Ilm. Adm. Publik, vol. 8, no. 2, pp. 537-552, 2007. 